\title{
PENGARUH DIVIDEND YIELD DAN EARNING VOLATILITY TERHADAP VOLATIVITAS HARGA SAHAM DI BURSA EFEK JAKARTA
}

\author{
Rani Ramdhani \\ Jurusan Manajemen, Fakultas Ekonomi dan Komunikasi, BINUS University \\ Jln. K.H. Syahdan No 9, Palmerah, Jakarta Barat 11480
}

\begin{abstract}
Some investors prefer dividend yield than capital gain, information signal follows to dividend policy that describes the earnings volatility in the future, which affects the stock price volatility on the Jakarta Stock Exchange.

Keywords :Dividend Yield, Earnings Volatility, Stock Price Volatility, Indonesian Stock Exchange

ABSTRAK

Sejumlah investor lebih mengutamakan dividend yield dibandingkan capital gain, sinyal informasi tersebut relevan dengan kebijakan dividen yang menggambarkan fluktuasi laba perusahaan di masa mendatang, yang pada akhirnya mempengaruhi fluktuasi harga saham tersebut di Bursa Efek Jakarta.
\end{abstract}

Kata kunci: hasil dividen, Volatilitas Laba, Volatilitas Harga Saham, Bursa Efek Jakarta 


\section{PENDAHULUAN}

Perdebatan tentang kebijakan dividen perusahaan terungkit dalam Roshid dan Rahman (2008). Mereka berasumsi bahwa dalam pasar modal sempurna, nilai perusahaan tidak dipengaruhi oleh pembagian dividen, nilai perusahaan ditentukan semata-mata oleh kekuatan earning perusahaan dan aliran earnings perusahaan yang dibagikan di antara dividen dan dana internal yang ditahan tidak mempengaruhi nilainya. Menurut Ross (2000) dari sudut pandang investor, sejumlah investor lebih memilih dividen saat ini (current dividend) dibanding dividen atau capital gain saat nanti, meskipun dividen yang dijanjikan itu lebih besar. Sedangkan menurut Nissim dan Ziv (2001) sinyaling atau muatan informasi dividen membawa informasi relevan kepada pemegang saham atau investor. Benartzi et al menyatakan bahwa perubahan kebijakan dividen membawa informasi tentang earning masa depan.

Namun demikian Miller dan Scholes (2001), pemegang saham tertentu bisa jadi tidak memilih dividen saat ini karena mereka sudah ada dalam tax bracket yang tinggi. Penahanan dana bisa jadi menunda potensi kewajiban pajak atau penahanan earning dalam bentuk dividen saham tercipta pada capital gain mendatang dalam bentuk kenaikan harga saham. Pajak capital gain biasanya lebih rendah dari pajak pendapatan marjinal pribadi dan dengan demikian ada efek klien dalam pandangan Kalay (2001). Akibat 'Free Cash Flow Hypothesis' Jensen (2000) manajer dengan arus kas bebas bisa meningkatkan dividen yang, bila tidak demikian, akan diinvestasikan dalam proyek return rendah atau pemborosan. Selain itu, keberadaan dividen kena pajak bisa menarik lebih banyak pemegang saham institusional, yang dapat terlibat langsung maupun tidak langsung dalam proes tata kelola perusahaan dan pada gilirannya dapat memperkenankan pengoperasian perusahaan yang baik demikian Allen et al (2000). Namun demikian Matherly (2002), ada suatu persoalan bahwa direktur dapat memanipulasi harga saham dengan mengumumkan dividen saham.

Permasalahan tersebut mendorong penulis untuk meneliti mengenai pengaruh kebijakan dividen terhadap volatilitas harga saham di Bursa Efek Indonesia pada periode 2002 - 2007, dengan rerumusan masalah adalah "Bagaimana pengaruh Dividend yield, dan Earning volatility terhadap volativitas Harga saham di Bursa Efek Indonesia?"

Tujuan yang ingin dicapai dalam penelitian ini adalah untuk menganalisis dan mengetahui apakah ada pengaruh dividend yield dan earning volatility terhadap harga volatility saham di Bursa Efek Indonesia.Adapun penelitian ini diharapkan dapat memberikan kontribusi kepada kepustakaan keuangan dengan mengurangi kelemahan studi dividen dan volatilitas harga saham dalam perekonomian berkembang. Keterbatasan dalam penelitian ini adalah mengacu pada penelitian Conroy et al (2000) yang dilakukan di Jepang. Sedangkan penelitian ini dilakukan di Indonesia khususnya pada perusahaan yang terdaftar di Bursa Efek Indonesia. Dan peneliti juga tidak dapat meneliti lebih dalam mengenai capital market, Ipo, secondary market dan serta juga yang mana tingkat bunga yang berubah akan mempengaruhi mengenai dividend serta earning terhadap price, diharapkan ada yang dapat meneliti lebih dalam untuk mengenai itu semua.

Definisi dividen menurut Weygant and Kieso dalam bukunya Accounting Priciples (2007:634) adalah : "A distribution by a corporation to its stockholders on a pro rata (proportional) basis". Sedangkan menurut Thomas R. Dyckman dalam bukunya Intermediate Accounting (2001:1071) adalah: "A dividend is a distribution of earnings to shareholders in the form of assets or shares of the issuing company's stock. A dividend is accounted for by a credit to the account that represents the item distributed (cash, non cash assets, or capital stock) and a debit to retained earnings”. Dengan kata lain, dividen merupakan bagian dari laba perusahaan yang berbentuk perseroan terbatas yang dibagikan kepada para pemegang saham. Besarnya pembagian dividen tersebut ditentukan dalam Rapat Umum Pemegang Saham (RUPS). 
Menurut Van Horn dalam bukunya Fundamental of Financial Management (2005), menyatakan bahwa pihak manajemen suatu perusahaan tidak terlepas dari 3 fungsi dalam pengambilan keputusan, yaitu: (1) Keputusan Investasi (Investment Decisions), (2) Keputusan Pembelanjaan (Financial Decisions), (3) Kebijakan Dividen (Dividend Policy). Jadi dari definisi diatas, dapat ditarik kesimpulan bahwa kebijakan dividen merupakan suatu kebijakan untuk menetapkan berapa bagian dari laba bersih yang akan dibagikan sebagai dividen kepada para pemegang saham dan berapa besar bagian dari laba bersih itu akan ditanamkan kembali sebagai laba ditahan oleh perusahaan untuk di reinvestasikan.

Dividen menurut Weygandt, Kieso, dan Kimmel (2002) merupakan pendistribusian laba oleh perusahaan kepada seluruh pemegang saham secara proporsional. Definisi lain Southwestern Publisher (2002) mengatakan dividen merupakan pembayaran kepada pemegang saham dari laba perusahaan, baik laba dari periode sekarang ataupun periode masa lampau.

Volatilitas adalah kecepatan naik turunya return sebuah reksadana. Volativitas tidak hanya terbatas pada reksadana namum juga seluruh instrumen investasi, baik saham, emas, obligasi atau instrumen-instrumen lainnya. Semakin tinggi volativitasnya, maka " kepastian " return suatu reksadana semakin rendah. Biasanya uang diunakan untuk mengukur volativitas stardanrd deviasi. Volatilitas earning merupakan simpang baku (standard deviation) rasio earning operasi perusahaan sebelum bunga dan pajak (EBIT) berbanding total asset. Dan menurut Mahadwartha (2002) menyatakan bahwa : "Earning volativity merupakan tingkat volativitas (perusahaan yang cepat) dari earning " dimana menurut Crutchley dan Hansen yang dikutip oleh Mahadwartha (2002), Volativitas earnings berkaitan dengan ekspectasi biaya kebangkrutan yang berpengaruh pada agency cost of debt. Lebih lanjut Petrovich At. Al (2006) menyatakan bahwa pihak investor atau pihak eksternal cenderung memperhatikan kondisi ini karena pada dasarnya respon pihak eksternal terhadap kenaikan earnings yang tak terduga akan sama dengan respon pihak eksternal terhadap penurunan earnings yang tidak terduga akan sama. Menurut Bathala Et. Al (1994) yang dikutip oleh Taswan (2003), earning volatility merupakan proxy dari resiko bisnis ( Business Risk ). Business risk merupakan resiko yang dihadapi oleh perusahaan.Business risk menurut Gitman (2003) adalah " resiko yang dihadapi oleh perusahaan dimana perusahaan tidak mampu menutup biaya operasional “.

Saham dapat didefinisikan tanda penyertaan atau kepemilikan seseorang atau badan dalam suatu perusahaan atau perseroan terbatas. Wujud saham adalah selembar kertas yang menerangkan bahwa pemilik kertas tersebut adalah pemilik perusahaan yang menerbitkan surat berharga tersebut. Porsi kepemilikan ditentukan dinyatakan Darmadji dan Fakhruddin (2001) oleh seberapa besar penyertaan yang ditanamkan di perusahaan tersebut. Menurut (Darmadji dan Fakhruddin, 2001) pergerakan harga saham dipengaruhi oleh faktor internal (lingkungan mikro) dan faktor eksternal (lingkungan makro). Berdasarkan uraian tersebut maka dapat diduga terdapat pengaruh signifikan antara dividend yield dan earning volatility terhadap price volatility.

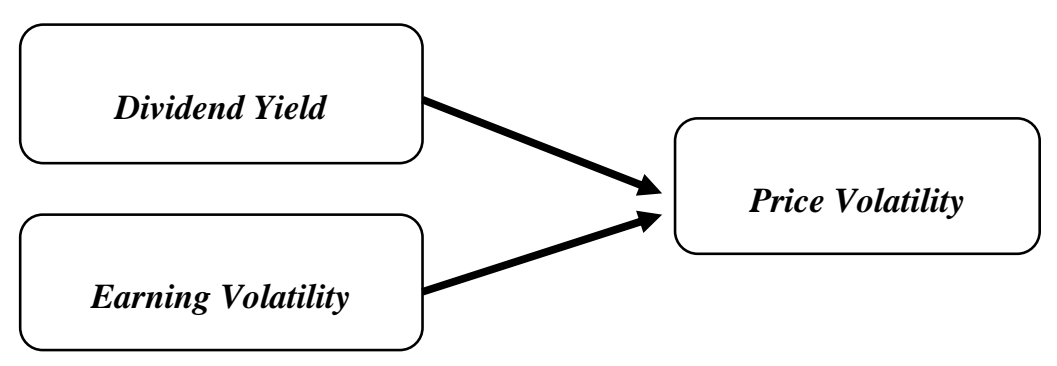

Gambar 1 Kerangka Konseptual 
Berdasarkan pembahasan di atas, hipotesis penelitian ini dapat diajukan:

$\mathrm{Ha}_{1}$ : $\quad$ Terdapat pengaruh signifikan Dividen Yield terhadap Price volatility

$\mathrm{Ha}_{2}$ : Terdapat pengaruh signifikan Earning Volatility terhadap Price Volatility

Penelitian ini bertujuan untuk melihat sejauh mana pengaruh antara variabel independent yang terdiri dari dividen yield (X1), earning volatility (X2), terhadap variable dependent yaitu price volatility saham melalui uji hipotesis.

\section{METODE PENELITIAN}

Penelitian ini mengacu pada penelitian Conroy et al (2000) yang dilakukan di Jepang. Metode penelitian yang digunakan adalah correlation research yang bertujuan untuk mendeteksi sejauh mana variasi pada suatu faktor berkaitan dengan variasi pada satu atau lebih faktor lain berdasarkan koefisien korelasi. Penelitian ini menggunakan data sekunder yang ada di Bursa Efek Indonesia guna menguji hipotesis mengenai pengaruh dividend yield dan earning volatility terhadap price volatility. Variabel bebas "independent variable" peneitian ini adalah dividend yield dan variabel tidak bebas "dependent variable" adalah price volatility sedangkan variabel perantara "intervening variable" adalah earning volatility. Metode penarikan sample yang digunakan pada penelitian ini adalah purposive sampling yaitu penarikan sample berdasarkan pertimbangan dimana sample yang dipilih didasarkan pada kriteria-kriteria tertentu. Studi ini mempertimbangkan data dalam periode 2002 2007 dengan Sampel populasi perusahan manufaktur yang terdaftar di bursa efek Indonesia. Penelitian ini menggunakan data sekuder. Data dikumpulkan berdasarkan informasi yang ada di Bursa Efek Indonesia terkait laporan tahunan perusahaan yang menjadi sampel penelitian. Model yang digunakan dalam studi ini dapat dispesifikasi sebagai P-VOL $=\alpha+\beta 1 \mathrm{D}-\mathrm{YIELD}+\beta 2 \mathrm{E}-\mathrm{VOL}+\beta 3 \mathrm{P}$, di mana, $\boldsymbol{\alpha}$ merupakan intercept, $\beta$ merupakan koefisien regresi dan $\varepsilon$ termin kesalahan. Selain itu data yang dikumpulkan dianalisis dengan menggunakan multiple regression. Tujuan analisis ini adalah untuk memprediksi perubahan-perubahan di dalam variabel terikat (dependent variable) dikaitkan dengan perubahan-perubahan yang terjadi dalam sejumlah variabel bebas (independent varible). Untuk kepentingan analisis data peneliti menggunakan bantuan program SPSS for Windows ver. 13.0. Apa bila analisis regresi linear sederhana didasarkan pada hubungan fungsional atau kausal satu variabel independen dengan satu variabel dependen, maka regresi linier berganda didasarkan pada hubungan fungsional atau kausal dua atau lebih variabel independen dengan satu variabel dependen. Di mana, $\boldsymbol{\alpha}$ merupakan intercept, $\beta$ merupakan koefisien regresi dan $\varepsilon$ termin kesalahan. Untuk kepentingan analisis data peneliti menggunakan bantuan program SPSS for Windows ver. 13.0.

\section{HASIL DAN PEMBAHASAN}

Sebelum dilakukan pengujian hipotesis dilakukan uji prasyarat analisis sehingga data penelitian dinyatakan telah memenuhi syarat untuk dilakukan pengujian selanjutnya. Ujia prasyarat analisis ini terdiri dari uji normalitas, uji multikolinieritas, uji autokorelasi, uji heteroskedasitas dan uji linieritas. Setelah melewati proses pengujian prasyarat analisis tersebut baru kemudian dilakukan pengujian hipotesis. 
Tabel 1Tabel Uji Correlations

\begin{tabular}{ccccc}
\hline & & Price_Volativity & Devidend_Yield & Earning_Volativity \\
\hline \multirow{2}{*}{ Pearson } & Price_Volativity & 1.000 & -.164 & .222 \\
Correlation & Devidend_Yield & -.164 & 1.000 & .064 \\
& Earning_Volativity & .222 & .064 & 1.000 \\
\hline \multirow{3}{*}{ Sig. (1-tailed) } & Price_Volativity &. & .014 & .001 \\
& Devidend_Yield & .014 &. & .198 \\
& Earning_Volativity & .001 & .198 &. \\
\hline \multirow{3}{*}{$\mathrm{N}$} & Price_Volativity & 180 & 180 & 180 \\
& Devidend_Yield & 180 & 180 & 180 \\
& Earning_Volativity & 180 & 180 & 180 \\
\hline
\end{tabular}

Tabel 2Tabel Uji Koefisien Determinasi

\begin{tabular}{ccccc}
\hline Model & R & R Square Adjusted R Square Std. Error of the Estimate \\
\hline 1 & $.285^{\mathrm{a}}$ & .081 & .071 & 2259.40661 \\
\hline
\end{tabular}

a. Predictors: (Constant), Earning Volatility, Dividend Yield

b. Dependent Variable: Price

Angka R Square (angka korelasi atau $\mathrm{r}$ yang dikuadratkan) sebesar 0,285 Angka R Square disebut juga sebagai Koefisien Determinasi. Besarnya angka Koefisien diterminasi 0,081 atau sama dengan $8,10 \%$. Angka tersebut berarti bahwa sebesar $8,10 \%$ variabel Price yang terjadi dapat dijelaskan dengan menggunakan variabel Earning Volatility dan variabel Dividen Yield. Sedang sisanya yaitu $91,90 \%(100 \%-8,10 \%)$ dapat dijelaskan oleh faktor-faktor penyebab lainnya.

Tabel 3 Tabel Uji ANOVA ${ }^{b}$

\begin{tabular}{|c|c|c|c|c|c|c|}
\hline \multicolumn{2}{|c|}{ Model } & $\begin{array}{c}\text { Sum of } \\
\text { Squares }\end{array}$ & Df & Mean Square & F & Sig. \\
\hline \multirow{3}{*}{1} & Regression & 7.980 & 2 & 3.990 & 7.816 & $.001^{\mathrm{a}}$ \\
& Residual & 9.036 & 177 & 5104918.249 & & \\
& Total & 9.834 & 179 & & & \\
\hline
\end{tabular}

a. Predictors: (Constant), Earning Volativity, Devidend Yield

b. Dependent Variable: Price Volativity

Uji ANOVA menghasilkan angka $\mathrm{F}$ sebesar 7,816 dengan tingkat signifikansi (angka probabilitas) sebesar 0,005 , karena angka probabilitas $0,0,001$ berarti lebih kecil dari 0,05, maka model regresi ini layak untuk digunakan dalam memprediksi variabel Price. Dengan kata lain, variabel Earning Volatility dan variabel Dividen Yield secara bersama-sama tidak mempengaruhi variabel Price. 
Tabel 4 Tabel Uji Coefficients ${ }^{a}$

\begin{tabular}{ccccccc}
\hline \multirow{2}{*}{ Model } & \multicolumn{2}{c}{ Unstandardized Coefficients } & Standardized Coefficients & & T & Sig. \\
\cline { 3 - 5 } & B & Std. Error & Beta & & \\
\hline & (Constant) & 882.059 & 292.048 & & 3.020 & .003 \\
1 & Divident Yield & -.355 & .143 & -.179 & -2.482 & .014 \\
& Earning Volatility & .241 & .074 & .233 & $3.230 \quad .001$ \\
\hline
\end{tabular}

a. Dependent Variable: Price

Persamaan regresinya: $\mathrm{Y}=882,059-0,355 \mathrm{X} 1+0,241 \mathrm{X} 2$

Dimana:

- $\quad \mathrm{Y}=$ Price

- $\quad \mathrm{X} 1=$ Dividen Yield

- $\quad \mathrm{X} 2$ = Earning Volatility

- Konstanta sebesar 822,059 mempunyai arti jika tidak ada variabel Dividen Yield dan variabel Earning Volativity, maka variabel Price sebesar 822,059.

- Koefisien regresi variabel Dividen Yield sebesar -0,355 mempunyai arti bahwa setiap penambahan 1 kali variabel Dividen Yield, maka variabel Price akan meningkat sebesar -0,355.

- Koefisien regresi variabel Earning Volatility sebesar 0,241 mempunyai arti bahwa setiap penambahan 1 kali variabel Earning Volatility, maka variabel Price akan meningkat sebesar 0,241.

Uji t pertama akan digunakan untuk menguji signifikansi konstanta dan variabel Dividen Yield, dengan menggunakan grafik akan terlihat:

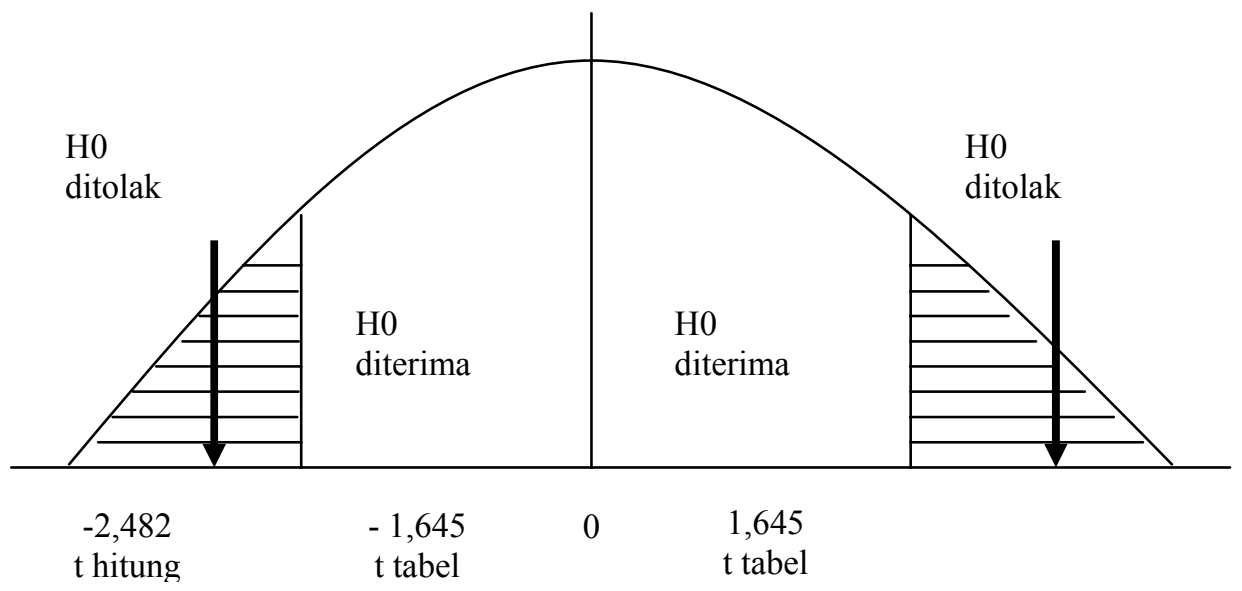

Karena $\mathrm{t}$ hitung jatuh di daerah penolakan, maka H0 ditolak. Artinya koefisien regresi signifikan. Kesimpulan, variabel Dividen Yield mempengaruhi variabel Price. Uji $t$ kedua akan digunakan untuk menguji signifikansi konstanta dan variabel Earning Volatility dengan menggunakan grafik akan terlihat: 


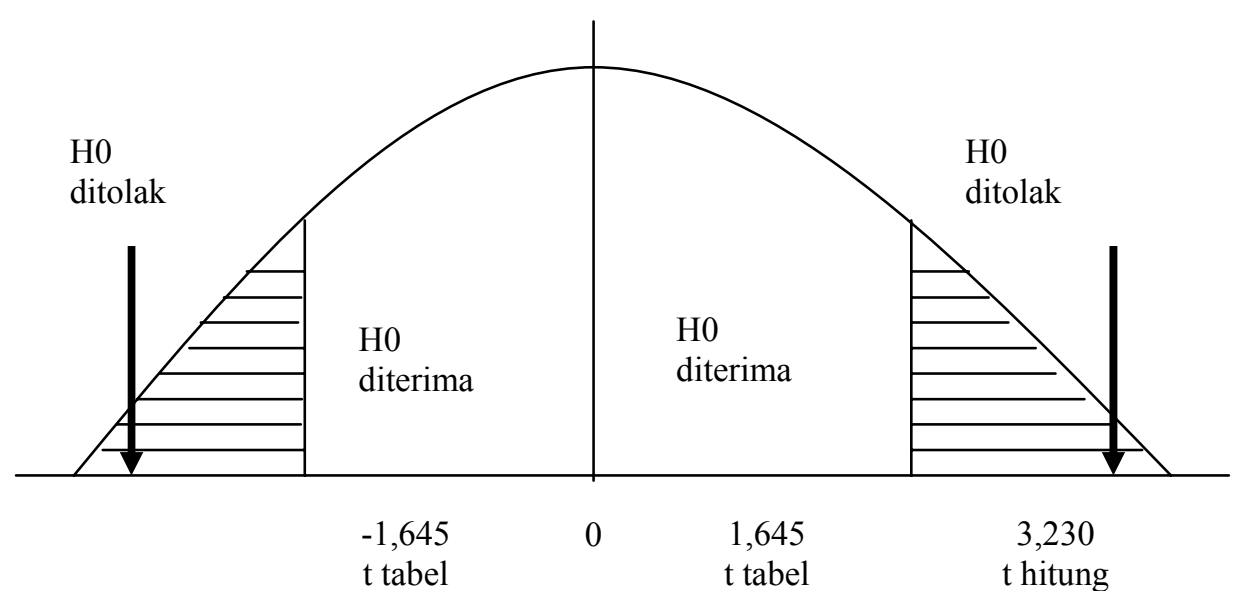

Karena t hitung jatuh di daerah penolakan, maka H0 ditolak. Artinya koefisien regresi signifikan. Kesimpulan, Earning Volatility mempengaruhi Price.

\section{SIMPULAN}

Berdasarkan hasil regresi diperoleh hubungan antara variabel bebas Dividend Yiled dan Earning Volativitas mempunyai koefisien korelasi -0,067, dengan demikian, hubungan kedua variabel tersebut sangat lemah. Korelasi negatif menunjukkan bahwa hubungan antara variabel Dividen Yield dengan variabel Price tidak searah. Artinya, jika variabel Dividen Yield kecil, maka variabel Price akan menurun. Earning Volatilitas dan Dividend Yiled berpengaruh signifikan terhadap Volatilitas Harga pada tingkat signifikansi 5\%. Melalui regresi berganda dapat diketahui bahwa variabel Dividend Yield cenderung berpengaruh negatif terhadap Price Volativity. Sedangkan variabel Earning Volativity cenderung berpengaruh positif terhadap Price Volativity. Uji ANOVA menghasilkan model regresi ini layak untuk digunakan dalam memprediksi variabel Price

\section{Saran}

Saran-saran yang dapat penulis kemukakan setelah melakukan penelitian ini antara lain, perlu dipahami bahwa hasil yang diperoleh dari penelitian ini hanya suatu pendekatan yang terjadi dalam kondisi normal atau ideal. Dengan kata lain kenyataannya tidak mutlak berlaku pada setiap kondisi, apa lagi dengan data yang tidak normal. Bagi pihak-pihak yang berkepentingan untuk menilai kaitan antara nilai Dividend Yield dan Earning Volativity pada industri manufaktur, sebaiknya melakukan pengamatan dan analisis lebih lanjut untuk mencari faktor-faktor lainnya yang mungkin lebih berpengaruh terhadap nilai perusahaan. Bagi para akademisi yang berminat untuk melakukan penelitian dengan membahas nilai perusahaan yang dikaitkan dengan kegiatan investasi, diharapkan bisa mengembangkannya dengan melakukan penelitian pada sektor industri lainnya atau pun dengan menggunakan faktor-faktor lain yang bisa berpengaruh signifikan terhadap nilai perusahaan. 


\section{DAFTAR PUSTAKA}

Accounting: Akuntansi Intermediate

Allen, F.; Bernardo, A. E. and Welch, I. (2000), A Theory of Dividends Based on Tax Clienteles, The Journal of Finance, 55 (6): 2499-3536.

Conroy R. M.; Eades, K. M. and Harris, R. S. (2000), A Test of The Relative Pricing Effects of Dividends and Earnings: Evidence from Simultaneous Announcements In Japan, The Journal of Finance, 55 (3): 1199-1227.

DeAngelo, H. and De Angelo, H. (2006), The Irrelevance of MM Dividend Irrelevance Theorem, Journal of Financial Economics, 79: 209-315.

Donald.E.Kieso, Weygandt.J.Jerry dan Warfield.D.Terry.2002.Intermediate Fransisco; Addison Wesley

Giman Lawrence J. (2003). Principles Of Managerial Finance 10th ed. San Inc. industri Rokok, Jurnal Riset Akuntansi Managemen dan Ekonomi.

Jensen, M. C. (2000), Agency Costs of Free Cash Flow, Corporate Finance and Takeovers, American Economic Review, Papers And Proceedings, 76: 323-329.

Kalay, A. (2001), The Ex-Dividend Day Behavior of Stock Prices: A Reexamination of the Clientele Effect, The Journal of Finance, 37 (4): 1059-1070.

Kebijakan Dividen, Jurnal Bisnis dan Ekonomi, Vol 10, 2000.

Kieso, Weygandt dan Kimmel .2007.Accounting Principle. John Wiley \& Sons

Mahadwartha, Putu Anom (2001), Analisis Ekonometri pengaruh Return, Vol

Mahadwartha, Putu Anom (2003), Uj Teori Keagenan dalam Hubungan Interdependensi antara Kebjakan Hutang danKebijakan Dividen.

Matherly, W. J. (2002), The Why of Stock Dividends, The University Journal of Business, 2 (1): 7280.

Nissim, D. and Ziv, A. (2001), Dividend Changes and Future Profitability, The Journal of Finance, 56 (6): 2111-2133.

Rylander, A., Jacobsen, K. and G. Roos "Towards Improved Information Disclosure on Intellectual Capital”, International Journal of Technology Management, Forthcoming Summer 2000

Simposium Nasional Akuntansi; Ikatan Akuntansi Indonesia.

Taswan (2003), Akuntansi Perbankan, UPP AMP YKPN, Semarang.

Thomas R. Dyckman dalam bukunya Intermediate Accounting (2001:1071) Darmaji, Tjiptono. Dan Hendy M. Fakhrudin. (2001) pasar modal di Indonesia : Pendekatan Tanya Jawa. Edisi Ke 1: Salemba Empat. Transaksi dan Resiko Unik Saham terhadap Beta Perusahaan pada

Van Horne, James C. And John M. Wachowicz, JR. (2005) Fundamental of Financial Management. Twelve Edition. Pearson Education Limited. 